\title{
GENDER AS A PARAMETER REFLECTING THE NON-SAVINGS DEPOSITS SITUATION OF INDIVIDUAL CUSTOMERS
}

\author{
Michał BARTNICKI \\ Silesian University of Technology; Michal.Bartnicki@polsl.pl, ORCID: 0000-0002-0998-4494
}

Purpose: The purpose of the research was to attempt a cross-sectional analysis indicating the distribution of customer deposits stored on the non-savings accounts, taking into account the main division of an account holder into gender and detailed distribution by age, balance amount and territorial location.

Design/methodology/approach: As part of this study, an analysis of data presenting the structure of individual customers with non-savings deposits, whose average monthly balance value exceeded PLN 6,000, have been presented. The main axis of the study is the categorisation and comparison of data based on gender. The study covers age and territorial sections as well as gradation of the amount of balances of stored deposits. The quantitative approach and the amount of balances of the accounts analysed are presented.

Findings: From a practical point of view, the potential investors or bonds issuers (treasury bonds, municipal bonds, etc.) looking for a capital, can do it among natural persons and address to them their offer and issue for them the prospectuses. When looking for free funds available on the market, they should also pay attention to the specificity resulting from the gender of an account holder. From the research point, distributions and differences in population behavior resulting from the account holder's gender are interesting.

Originality/value: The basic content of the article is a new and original approach to the analysis of data on non-savings accounts which includes gender as the basic parameter of division into groups.

Keywords: non-savings deposits, account structure, account deposits.

\section{Introduction}

Customer segmentation is one of the basic trends of current banking. Banks divide into various categories and, depending on the categorisation carried out, adapt entire business models and product offer profiled to customer expectations. Separating homogeneous groups better helps meet customer expectations. It also allows to carry out marketing campaigns more effectively. Segmentation is also helpful in the case of institutions and organisations that may be looking for unspent funds (capital) to carry out investments. 
Together with the publication of W.R. Smith in 1956 (Smith, 1956) segmentation became a widely known tool used in building systems that makes it possible the distinguish homogeneous groups. Research issues concerning the structure of current account customers' accounts in Poland were discussed in the article "Segmentation as the basis for diversifying marketing activities" (Szulce, Florek, Walkowiak, 2004). In turn, the topic of market segmentation along with the criteria and methods of division is discussed in the work prepared by professor Marek Walesiak (Walesiak, 2013). Additionally, the analysis of the population by the state and structure, and their natural movement in territorial cross-section in 2018 is also discussed in the publication of the Statistics Poland published on the website https://stat.gov.pl/obszary-tematyczne/ludnosc/ludnosc/ludnosc-stan-i-struktura-oraz-ruchnaturalny-w-przekroju-terytorialnym-w-2018-r-stan-w-dniu-31-xii,6,25.html.

One of the basic segmentation criteria is the gender and age of the customer. The purpose of this study is to analyse the availability of unspent capital in the form of deposits on non-savings (current) accounts, broken down by gender of the holders.

Following the latest report published by the National Bank of Poland, which concerns the financial situation of the household sector, it can be assumed that a certain portion of the financial surplus is not allocated to additional current consumption and is not invested. This surplus remains as an increasing deposit of funds on interest-free current accounts of individual customers (Kolasa, 2017).

The presented research assumes that financial surpluses over PLN 6,000 are financial surpluses which, without prejudice to the current functioning of an average household, can be invested in the broadly understood capital market, for example in the form of short-term and long-term investments.

Deposits above PLN 6,000 were designated for accounts with an average monthly balance exceeding the assumed quota threshold. Therefore, the values were analysed, which are a permanent financial surplus, and not a temporary one, resulting from current financial movements on the accounts, which mainly come from the influence of remuneration from the employment relationship.

Contemporary capital markets give investors, both individual and institutional, a wide range of instruments to invest and multiply their assets. A significant part of capital on the capital market comes from individual investors (Dziawgo, 2006; Fatuła, 2007). However, a large number of individuals with financial surpluses do not invest them but hold onto them, whether in the form of cash or on non-saving current accounts (Strzelecka, 2010; Iwanicz-Drozdowska, 2008). As part of the research, over 860 thousand non-savings accounts of individual customers were analysed, whose total balance was over PLN 15 billion. 


\section{Input data and their initial classification}

The study covered 860,141 non-savings bank accounts with an average monthly core deposit of at least PLN 6,000, have been presented. For some accounts, the value of core deposits, such as accounts for current use, was very high. It was found that for 45 accounts, the average monthly core deposit exceeded PLN 1 million, and in individual cases 4, 5 and 6 million, respectively.

Input data was classified according to several categories, included among which are: balance, age, gender, territorial location (commune, poviat, province).

The 'Balance' category was analysed by class. The list was divided into 9 classes (in PLN thousand):

1. 6.00-7.49.

2. $7.50-9.99$.

3. 10.00-14.99.

4. $15.00-29.99$.

5. $30.00-49.99$.

6. 50.00-99.99.

7. $100.00-249.99$.

8. 250.00-499.99.

9. Above 500 .

The age of the account holder was determined on the basis of the date of birth of the main bank account holder, which means that in the case of an account having several co-owners, only the main owner's data was relevant. As part of obtaining data for research, it was not possible to specify the distinguishing feature that would indicate those accounts that are assigned to one holder and which have many owners. Guided by the division into age categories that are used by Statistics Poland (GUS, 2018), the category method was grouped every 5 years, except that all persons up to the age of 14 and persons over 100 years old were classified into individual groups.

'Province' category data was determined on the basis of the main account holder's registered place of residence, which means that in the case of an account having several co-owners, only the main owner's data was relevant.

'Gender' category data was determined on the basis of the main owner's gender, which means that in the case of an account having several co-owners, only the main owner's data was relevant. 


\section{Age categories according to Statistics Poland (GUS)}

The age categories were adopted in accordance with the GUS classification of 31/12/2018 (https://stat.gov.pl/obszary-tematyczne/ludnosc/ludnosc/ludnosc-stan-i-struktura-oraz-ruchnaturalny-w-przekroju-terytorialnym-w-2018-r-stan-w-dniu-31-xii,6,25.html).

The age ranges adopted for studying are presented in Table 1. Compared to the GUS classification, categories 0-4 and 5-9 years are omitted, for which it is not possible to run an independent bank account

\section{Table 1.}

Age categories

\begin{tabular}{|c|c|c|}
\hline Age & Age & Age \\
\hline$\underline{\theta-4 \text { years }}$ & $35-39$ & $70-74$ \\
\hline$\underline{5-9}$ & $40-44$ & $75-79$ \\
\hline $10-14$ & $45-49$ & $80-84$ \\
\hline $15-19$ & $50-54$ & $85-89$ \\
\hline $20-24$ & $55-59$ & $90-94$ \\
\hline $25-29$ & $60-64$ & $95-99$ \\
\hline $30-34$ & $65-69$ & 100 and more \\
\hline
\end{tabular}

Source: https://stat.gov.p1/obszary-tematyczne/ludnosc/ludnosc/ludnosc-stan-i-struktura-oraz-ruchnaturalny-w-przekroju-terytorialnym-w-2018-r-stan-w-dniu-31-xii,6,25.html.

\section{Analysis according to individual categories}

The analysis within the framework of this study was based on a comparison of 4 categories in which the relevant classes were defined:

1. Category 'Balance' - divided into classes as described in chapter 2.

2. Category 'Age' - divided into classes as described in chapter 3.

3. Category 'Gender' - female/male.

4. Category 'Province' - according to the country's territorial division into 16 provinces. The study presents 3 sets for pairs of classes, respectively:

1. Gender - Province.

2. Gender - Balance.

3. Gender - Age.

Each set of pairs was analysed in two systems:

1. By value as the sum of the values of the balances included in the class.

2. Quantitatively as the number of accounts included in the class.

The three approaches depict the territorial distribution of groups of average monthly balances and age broken down by gender. Looking at the national scale in terms of quantity, the distribution of the number of accounts belonging to men and women is evenly distributed 
$(50 \% / 50 \%)$. At the same time, in terms of value, it is taken into account that larger amounts of non-savings deposits are kept by men $(53 \% / 47 \%)$.

\subsection{Gender - Province}

Table 2 presents the first approach in terms of both value and quantity in territorial division to the level of provinces. Within all provinces, a predominance of men in terms of value can be seen. The strongest predominance in terms of value occurs in the Silesia Province (58/42) and the greatest value balance occurs in the Mazovia Province (50/50). The territorial distribution in terms of quantity is completely different. In five provinces, women have the predominance. The largest in the Mazovia Province (47/53). There is balance in five provinces. In the remaining six men have the predominance.

Table 2.

Value of balances and number of accounts broken down by gender in terms of province

\begin{tabular}{|c|c|c|c|c|c|c|c|c|c|c|}
\hline & \multicolumn{5}{|c|}{ By value (PLN thousand) } & \multicolumn{5}{|c|}{ Quantitative (pcs.) } \\
\hline Province/Gender & Female & Male & Total & $\begin{array}{c}\% \% \\
\text { Female }\end{array}$ & $\begin{array}{c}\% \\
\text { Male }\end{array}$ & Female & Male & Total & \begin{tabular}{c|}
$\%$ \\
Female \\
\end{tabular} & $\begin{array}{c}\% \\
\text { Male }\end{array}$ \\
\hline Opole & 131,869 & 149,385 & 281,254 & $47 \%$ & $53 \%$ & 8,494 & 8,389 & 16,883 & $50 \%$ & $50 \%$ \\
\hline Świętokrzyskie & 171,659 & 204,936 & 376,595 & $46 \%$ & $54 \%$ & 10,532 & 11,122 & 21,654 & $49 \%$ & $51 \%$ \\
\hline Podlaskie & 188,032 & 201,092 & 389,124 & $48 \%$ & $52 \%$ & 11,747 & 11,361 & 23,108 & $51 \%$ & $49 \%$ \\
\hline Lubusz & 184,963 & 207,022 & 391,985 & $47 \%$ & $53 \%$ & 11,541 & 11,252 & 22,793 & $51 \%$ & $49 \%$ \\
\hline Subcarpathia & 223,078 & 266,232 & 489,310 & $46 \%$ & $54 \%$ & 13,726 & 14,936 & 28,662 & $48 \%$ & $52 \%$ \\
\hline Warmia-Masuria & 257,992 & 293,898 & 551,890 & $47 \%$ & $53 \%$ & 16,018 & 16,122 & 32,140 & $50 \%$ & $50 \%$ \\
\hline West Pomerania & 304,038 & 344,869 & 648,906 & $47 \%$ & $53 \%$ & 17,537 & 17,878 & 35,415 & $50 \%$ & $50 \%$ \\
\hline Lublin & 304,799 & 356,975 & 661,774 & $46 \%$ & $54 \%$ & 18,925 & 19,564 & 38,489 & $49 \%$ & $51 \%$ \\
\hline Pomerania & 308,059 & 376,115 & 684,174 & $45 \%$ & $55 \%$ & 18,690 & 20,143 & 38,833 & $48 \%$ & $52 \%$ \\
\hline Kuyavia-Pomerania & 398,629 & 433,327 & 831,956 & $48 \%$ & $52 \%$ & 23,713 & 23,286 & 46,999 & $50 \%$ & $50 \%$ \\
\hline Lesser Poland & 477,325 & 549,136 & $1,026,460$ & $47 \%$ & $53 \%$ & 28,447 & 29,731 & 58,178 & $49 \%$ & $51 \%$ \\
\hline Lódzkie & 560,636 & 596,006 & $1,156,642$ & $48 \%$ & $52 \%$ & 34,125 & 32,184 & 66,309 & $51 \%$ & $49 \%$ \\
\hline Lower Silesia & 611,257 & 656,606 & $1,267,863$ & $48 \%$ & $52 \%$ & 36,158 & 34,394 & 70,552 & $51 \%$ & $49 \%$ \\
\hline Greater Poland & 831,804 & 938,955 & $1,770,759$ & $47 \%$ & $53 \%$ & 47,129 & 48,071 & 95,200 & $50 \%$ & $50 \%$ \\
\hline Silesia & 756,374 & $1,035,079$ & $1,791,453$ & $42 \%$ & $58 \%$ & 47,722 & 58,512 & 106,234 & $45 \%$ & $55 \%$ \\
\hline Mazovia & $1,674,919$ & $1,661,538$ & $3,336,457$ & $50 \%$ & $50 \%$ & 84,153 & 74,539 & 158,692 & $53 \%$ & $47 \%$ \\
\hline Total & $7,385,432$ & $8,271,170$ & $15,656,602$ & $47 \%$ & $53 \%$ & 428,657 & 431,484 & 860,141 & $50 \%$ & $50 \%$ \\
\hline
\end{tabular}

Source: Own study.

Figure 1 presents the value distribution of deposits by individual provinces with an additional distinction showing what percentage of the volume belongs to women. By far the highest deposits belong to owners who have accounts in the Mazovia Province, but also in this province there is the greatest balance between women and men. In turn, the second largest visible disproportion between men and women in terms of the value of deposits is found in the Silesia Province. Here, the value balance of women is lower than that of women in the third overall most valuable province of Greater Poland. 


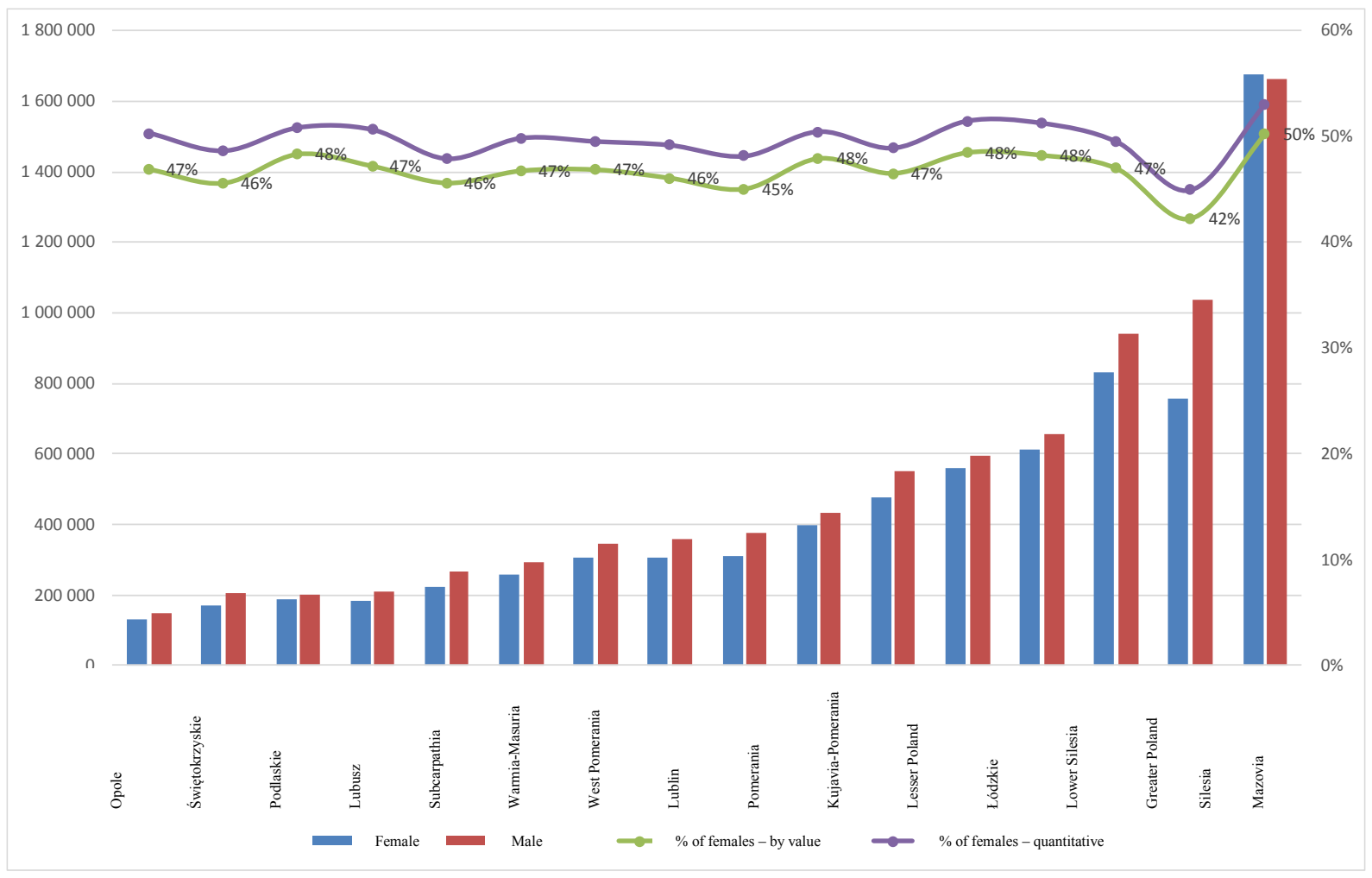

Figure 1. Value distribution of female / male broken down by province

As part of the comparative gender analysis against the background of provinces, one can notice a lasting difference between the quantity and value share of women and men. Quantitatively, women have a 2-3\% larger share than value. The maximum difference in this approach is $3.45 \%$ and the minimum is $2.30 \%$. The conclusion can be drawn that in the quantitative approach we have a balance between women and men on a national scale. An even distribution between provinces can also be seen here. If you look at the value approach, you can see the predominance of men on a national scale. Balance only occurs in the Mazovia Province. The result is a lower average balance among women.

When comparing quantitatively the share of women's and men's accounts, no reference was made to the size of the population of women and men living in a given province. Table 3 presents the reference of shares of the number of accounts to shares of women and men living in a given area. The value of 1 indicator in the last columns should be interpreted as equal to the value of the share of accounts in relation to the share of each gender living in the indicated area.

When illustrating the situation in this approach, it should be noted that except for the Mazovia Province, the indicator for women is lower than for men everywhere, which means less saturation with the studied type of accounts in the total population.

In addition to the Mazovia Province, the Silesia Province is also distinctive. In this province one can notice a definite predominance of men both in terms of value and quantity. Also the ratio of reference to the proportion of the population is clearly lower in women than in other 
provinces. The reason for this may be a deeply rooted model of maintaining a family or / and holding joint accounts by spouses, where the main owner is a man.

Table 3.

The share of the number of accounts in comparison to the ratio of persons residing in a given province by gender

\begin{tabular}{|c|c|c|c|c|c|c|c|c|c|c|c|c|}
\hline \multirow[b]{2}{*}{ Province/Gender } & \multicolumn{5}{|c|}{ Number of accounts (pcs.) } & \multicolumn{5}{|c|}{ Number of residents (thousand people) } & \multicolumn{2}{|c|}{$\begin{array}{l}\text { Share ratio of } \\
\text { accounts to } \\
\text { population }\end{array}$} \\
\hline & Female & Male & Total & $\begin{array}{c}\% \% \\
\text { Female }\end{array}$ & $\begin{array}{c}\% \\
\text { Male }\end{array}$ & Female & Male & Total & $\begin{array}{c}\% \\
\text { Female }\end{array}$ & $\begin{array}{c}\% \\
\text { Male }\end{array}$ & Female & Male \\
\hline Opole & 8,494 & 8,389 & 16,883 & $50 \%$ & $50 \%$ & 509 & 477 & 987 & $52 \%$ & $48 \%$ & 0.97 & 1.03 \\
\hline Świętokrzyskie & 10,532 & 11,122 & 21,654 & $49 \%$ & $51 \%$ & 636 & 605 & 1,242 & $51 \%$ & $49 \%$ & 0.95 & 1.05 \\
\hline Podlaskie & 11,747 & 11,361 & 23,108 & $51 \%$ & $49 \%$ & 606 & 576 & 1,182 & $51 \%$ & $49 \%$ & 0.99 & 1.01 \\
\hline Lubusz & 11,541 & 11,252 & 22,793 & $51 \%$ & $49 \%$ & 521 & 494 & 1,015 & $51 \%$ & $49 \%$ & 0.99 & 1.01 \\
\hline Subcarpathia & 13,726 & 14,936 & 28,662 & $48 \%$ & $52 \%$ & 1,086 & 1,043 & 2,129 & $51 \%$ & $49 \%$ & 0.94 & 1.06 \\
\hline Warmia-Masuria & 16,018 & 16,122 & 32,140 & $50 \%$ & $50 \%$ & 730 & 699 & 1,429 & $51 \%$ & $49 \%$ & 0.98 & 1.03 \\
\hline West Pomerania & 17,537 & 17,878 & 35,415 & $50 \%$ & $50 \%$ & 874 & 827 & 1,701 & $51 \%$ & $49 \%$ & 0.96 & 1.04 \\
\hline Lublin & 18,925 & 19,564 & 38,489 & $49 \%$ & $51 \%$ & 1,091 & 1,026 & 2,118 & $52 \%$ & $48 \%$ & 0.95 & 1.05 \\
\hline Pomerania & 18,690 & 20,143 & 38,833 & $48 \%$ & $52 \%$ & 1,197 & 1,136 & 2,334 & $51 \%$ & $49 \%$ & 0.94 & 1.07 \\
\hline $\begin{array}{c}\text { Kuyavia- } \\
\text { Pomerania }\end{array}$ & 23,713 & 23,286 & 46,999 & $50 \%$ & $50 \%$ & 1,071 & 1,007 & 2,078 & $52 \%$ & $48 \%$ & 0.98 & 1.02 \\
\hline Lesser Poland & 28,447 & 29,731 & 58,178 & $49 \%$ & $51 \%$ & 1,750 & 1,651 & 3,401 & $51 \%$ & $49 \%$ & 0.95 & 1.05 \\
\hline Lódzkie & 34,125 & 32,184 & 66,309 & $51 \%$ & $49 \%$ & 1,291 & 1,175 & 2,466 & $52 \%$ & $48 \%$ & 0.98 & 1.02 \\
\hline Lower Silesia & 36,158 & 34,394 & 70,552 & $51 \%$ & $49 \%$ & 1,506 & 1,395 & 2,901 & $52 \%$ & $48 \%$ & 0.99 & 1.01 \\
\hline Greater Poland & 47,129 & 48,071 & 95,200 & $50 \%$ & $50 \%$ & 1,794 & 1,700 & 3,494 & $51 \%$ & $49 \%$ & 0.96 & 1.04 \\
\hline Silesia & 47,722 & 58,512 & 106,234 & $45 \%$ & $55 \%$ & 2,348 & 2,185 & 4,534 & $52 \%$ & $48 \%$ & 0.87 & 1.14 \\
\hline Mazovia & 84,153 & 74,539 & 158,692 & $53 \%$ & $47 \%$ & 2,818 & 2,585 & 5,403 & $52 \%$ & $48 \%$ & 1.02 & 0.98 \\
\hline Total & 428,657 & 431,484 & 860,141 & $50 \%$ & $50 \%$ & 19,829 & 18,582 & 38,411 & $52 \%$ & $48 \%$ & 0.97 & 1.04 \\
\hline
\end{tabular}

\subsection{Gender - Balance}

The next approach in terms of value and quantity, broken down into ranges of average monthly balances, is presented in Table 4 . In this system one can notice a constant tendency to change the proportion between women and men together with the increase in the average monthly value of the balance. For the first two classes between PLN 6-9.99 thousand, a predominance of women can be seen. In the class of 10-14.99 thousand. there is equalisation in terms of both value and quantity. In the upper classes there is an increasingly pronounced shift in both value and quantity towards men. In the highest class, in which the average monthly balances exceed PLN 500,000, the value predominance of men is $62 / 38$ and the quantity predominance is 64/36. In addition, it can be noted that the trend in terms of value and quantity is very similar. 
Table 4.

The value of balances and the number of accounts broken down by gender in terms of the group of average monthly deposits

\begin{tabular}{|c|c|c|c|c|c|c|c|c|c|c|}
\hline & $\begin{array}{l}\text { By value ( } \\
\text { thousand) }\end{array}$ & & & & & $\begin{array}{l}\text { Quanti- } \\
\text { tative }\end{array}$ & & & & \\
\hline $\begin{array}{l}\text { Balance/ } \\
\text { Gender }\end{array}$ & Female & Male & Total & $\begin{array}{c}\% \\
\text { Female }\end{array}$ & $\begin{array}{c}\% \\
\text { Male }\end{array}$ & Female & Male & Total & $\begin{array}{c}\% \\
\text { Female }\end{array}$ & $\begin{array}{c}\% \\
\text { Male }\end{array}$ \\
\hline $6.00-7.49$ & 568,676 & 497,545 & $1,066,220$ & $53 \%$ & $47 \%$ & 85,125 & 74,440 & 159,565 & $53 \%$ & $47 \%$ \\
\hline $7.50-9.99$ & 831,682 & 774,140 & $1,605,822$ & $52 \%$ & $48 \%$ & 96,699 & 89,944 & 186,643 & $52 \%$ & $48 \%$ \\
\hline $10.00-14.99$ & $1,261,552$ & $1,251,884$ & $2,513,436$ & $50 \%$ & $50 \%$ & 104,375 & 103,398 & 207,773 & $50 \%$ & $50 \%$ \\
\hline $15.00-29.99$ & $1,949,109$ & $2,154,514$ & $4,103,623$ & $47 \%$ & $53 \%$ & 95,125 & 104,401 & 199,526 & $48 \%$ & $52 \%$ \\
\hline $30.00-49.99$ & $1,084,713$ & $1,333,201$ & $2,417,913$ & $45 \%$ & $55 \%$ & 28,825 & 35,260 & 64,085 & $45 \%$ & $55 \%$ \\
\hline $50.00-99.99$ & 938,049 & $1,202,211$ & $2,140,260$ & $44 \%$ & $56 \%$ & 14,113 & 17,990 & 32,103 & $44 \%$ & $56 \%$ \\
\hline $\begin{array}{c}100.00- \\
249.99\end{array}$ & 556,857 & 759,273 & $1,316,130$ & $42 \%$ & $58 \%$ & 3,929 & 5,345 & 9,274 & $42 \%$ & $58 \%$ \\
\hline $\begin{array}{c}250.00- \\
499.99\end{array}$ & 127,418 & 190,613 & 318,030 & $40 \%$ & $60 \%$ & 395 & 580 & 975 & $41 \%$ & $59 \%$ \\
\hline Above 500 & 67,377 & 107,791 & 175,168 & $38 \%$ & $62 \%$ & 71 & 126 & 197 & $36 \%$ & $64 \%$ \\
\hline Total & $7,385,432$ & $8,271,170$ & $15,656,602$ & $47 \%$ & $53 \%$ & 428,657 & 431,484 & 860,141 & $50 \%$ & $50 \%$ \\
\hline
\end{tabular}

Source: Own study.

Figure 2 presents the value distribution in individual balance classes. As can be seen, the most non-saving deposits for both men and women were collected on accounts with an average monthly balance of PLN 15-29.99 thousand.

The largest accounts accumulate a relatively small amount of capital in total.

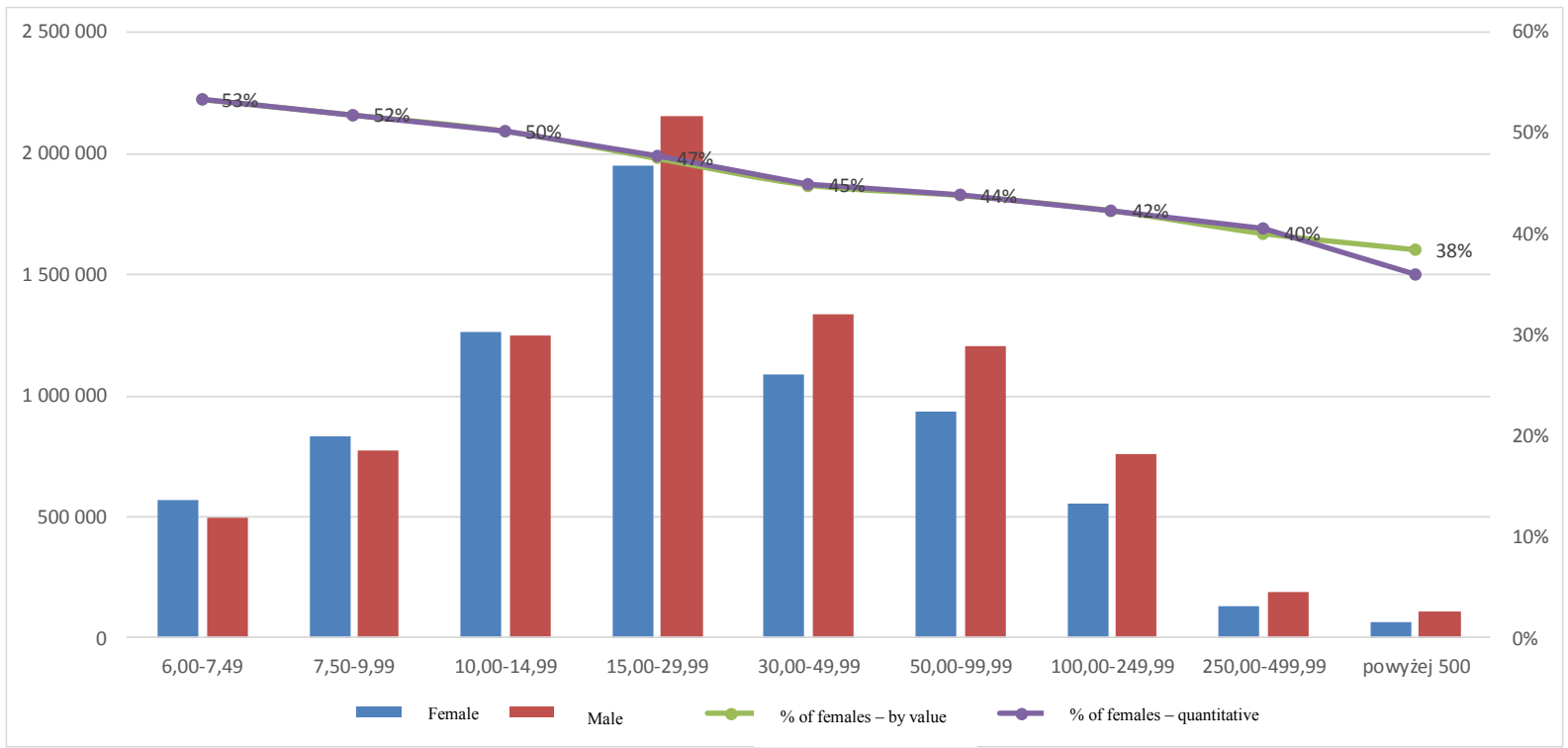

Figure 2. Value distribution of female / male broken down by balance class.

\subsection{Gender - Age}

The last approach in terms of value and quantity broken down into age range is presented in Table 5. In this approach, very interesting phenomena can be observed. 
Table 5.

The value of balances and the number of accounts broken down by gender in terms of age ranges

\begin{tabular}{|c|c|c|c|c|c|c|c|c|c|c|}
\hline \multirow[b]{2}{*}{ Age/Gender } & \multicolumn{2}{|c|}{$\begin{array}{l}\text { By value (PLN } \\
\text { thousand) }\end{array}$} & \multirow[b]{2}{*}{ Total } & \multirow[b]{2}{*}{$\begin{array}{c}\% \\
\text { Female } \\
\end{array}$} & \multirow[b]{2}{*}{$\begin{array}{c}\% \\
\text { Male }\end{array}$} & \multirow{2}{*}{$\begin{array}{l}\text { Quanti- } \\
\text { tative (pcs.) } \\
\text { Female }\end{array}$} & \multirow[b]{2}{*}{ Male } & \multirow[b]{2}{*}{ Total } & \multirow[b]{2}{*}{$\begin{array}{c}\% \\
\text { Female } \\
\end{array}$} & \multirow[b]{2}{*}{$\begin{array}{c}\% \\
\text { Male } \\
\end{array}$} \\
\hline & Female & Male & & & & & & & & \\
\hline $10-14$ & 82 & 43 & 125 & $66 \%$ & $34 \%$ & 3 & 4 & 7 & $43 \%$ & $57 \%$ \\
\hline 15-19 & 4,198 & 3,516 & 7,714 & $54 \%$ & $46 \%$ & 268 & 279 & 547 & $49 \%$ & $51 \%$ \\
\hline $20-24$ & 52,376 & 68,947 & 121,323 & $43 \%$ & $57 \%$ & 3,853 & 4,976 & 8,829 & $44 \%$ & $56 \%$ \\
\hline $25-29$ & 254,178 & 348,584 & 602,762 & $42 \%$ & $58 \%$ & 16,804 & 20,749 & 37,553 & $45 \%$ & $55 \%$ \\
\hline $30-34$ & 490,624 & 640,123 & $1,130,747$ & $43 \%$ & $57 \%$ & 27,599 & 32,804 & 60,403 & $46 \%$ & $54 \%$ \\
\hline 35-39 & 594,185 & 768,102 & $1,362,287$ & $44 \%$ & $56 \%$ & 31,777 & 36,767 & 68,544 & $46 \%$ & $54 \%$ \\
\hline $40-44$ & 606,020 & 770,573 & $1,376,592$ & $44 \%$ & $56 \%$ & 31,878 & 36,828 & 68,706 & $46 \%$ & $54 \%$ \\
\hline $45-49$ & 627,648 & 779,438 & $1,407,086$ & $45 \%$ & $55 \%$ & 34,255 & 38,094 & 72,349 & $47 \%$ & $53 \%$ \\
\hline $50-54$ & 774,874 & 882,337 & $1,657,211$ & $47 \%$ & $53 \%$ & 43,486 & 43,761 & 87,247 & $50 \%$ & $50 \%$ \\
\hline $55-59$ & $1,012,329$ & $1,038,931$ & $2,051,260$ & $49 \%$ & $51 \%$ & 57,485 & 52,271 & 109,756 & $52 \%$ & $48 \%$ \\
\hline $60-64$ & 985,580 & 978,749 & $1,964,329$ & $50 \%$ & $50 \%$ & 57,109 & 51,088 & 108,197 & $53 \%$ & $47 \%$ \\
\hline 65-69 & 622,496 & 711,500 & $1,333,996$ & $47 \%$ & $53 \%$ & 38,319 & 38,368 & 76,687 & $50 \%$ & $50 \%$ \\
\hline $70-74$ & 393,890 & 414,033 & 807,923 & $49 \%$ & $51 \%$ & 24,879 & 24,477 & 49,356 & $50 \%$ & $50 \%$ \\
\hline $75-79$ & 369,722 & 344,727 & 714,450 & $52 \%$ & $48 \%$ & 24,332 & 21,380 & 45,712 & $53 \%$ & $47 \%$ \\
\hline $80-84$ & 300,198 & 267,280 & 567,477 & $53 \%$ & $47 \%$ & 19,206 & 16,221 & 35,427 & $54 \%$ & $46 \%$ \\
\hline $85-89$ & 201,957 & 176,355 & 378,312 & $53 \%$ & $47 \%$ & 12,120 & 9,540 & 21,660 & $56 \%$ & $44 \%$ \\
\hline $90-94$ & 78,570 & 64,217 & 142,787 & $55 \%$ & $45 \%$ & 4,420 & 3,279 & 7,699 & $57 \%$ & $43 \%$ \\
\hline 95-99 & 14,531 & 11,246 & 25,777 & $56 \%$ & $44 \%$ & 766 & 530 & 1,296 & $59 \%$ & $41 \%$ \\
\hline $\begin{array}{c}100 \text { years and } \\
\text { older }\end{array}$ & 1,975 & 2,471 & 4,445 & $44 \%$ & $56 \%$ & 98 & 68 & 166 & $59 \%$ & $41 \%$ \\
\hline Total & $7,385,432$ & $8,271,170$ & $15,656,602$ & $47 \%$ & $53 \%$ & 428,657 & 431,484 & 860,141 & $50 \%$ & $50 \%$ \\
\hline
\end{tabular}

Source: Own study.

Both men and women accumulate the most non-savings deposits in the age ranges 55-64. These are periods in which the share in the value structure is more or less equal. In the next age range (65-69 years) there is a clear decrease in the value of non-savings deposits for both women and men. With the fact that for women the reduction is significantly greater than for men. It should be noted that for women it is the second age range after reaching retirement age, and for men it is the direct period after reaching retirement age.

The quantitative approach shows the share predominance of women by several percent in relation to the share of the whole range of age groups. Only the first two (youngest) groups are exceptions (Figure 3). 


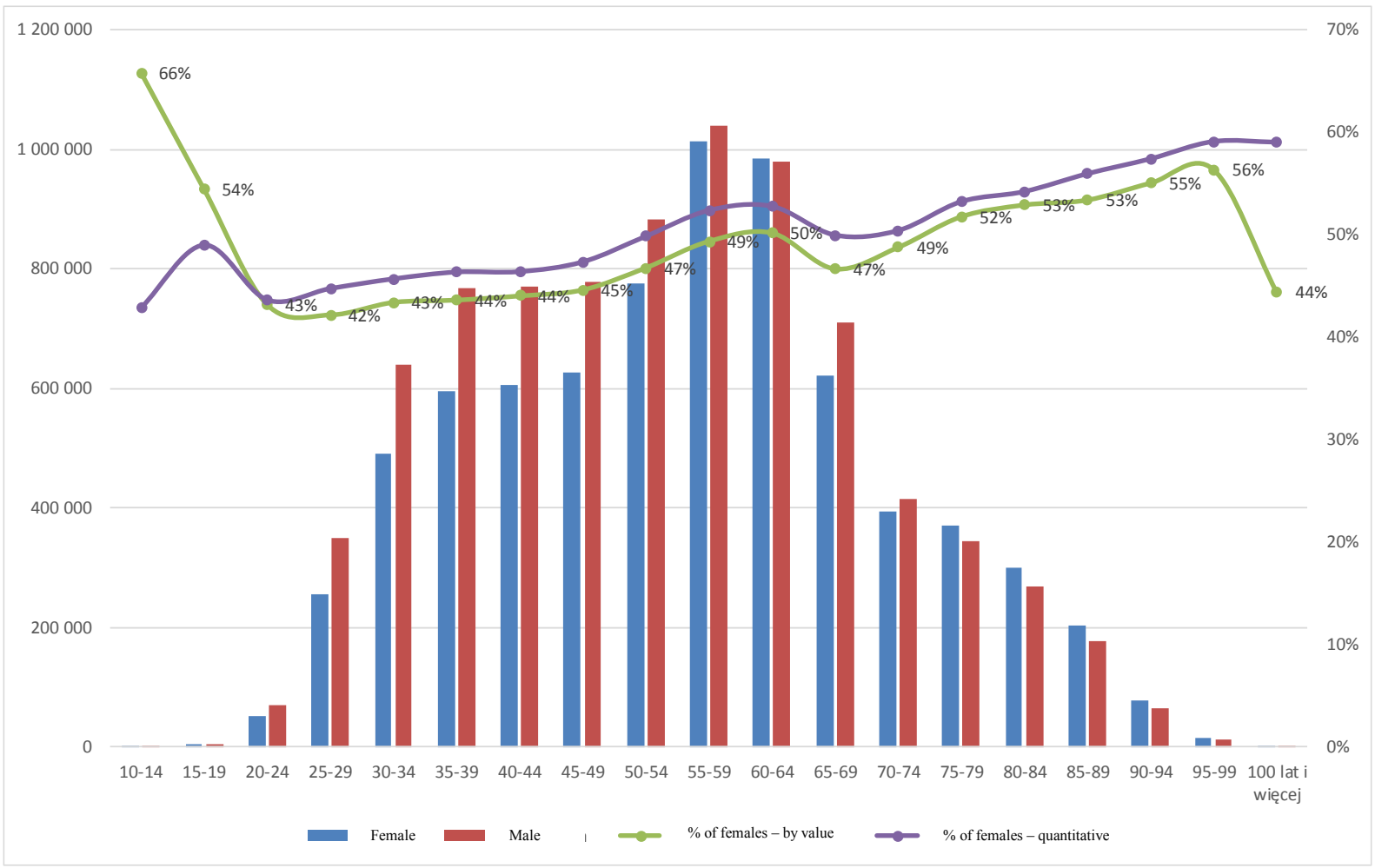

Figure 3. Value distribution of female / male broken down by age.

\section{Conclusions}

Based on the data presented, several very interesting conclusions can be drawn. The most important is the conclusion that individual customers have a very high value of uninvested funds kept on interest-free current accounts. Such funds are in the accounts of both women and men. Based on the analysis of individual sections, it can be concluded that the potential investor is a man aged 55-65 (the largest number of people and the largest percentage of people in this age category) living in the province:

1. Mazovia (very high number of people, very high balances, very high percentage of the population meeting the criteria).

2. Silesia and Greater Poland (large number of people, high deposits, high percentage of the population meeting the criteria).

3. Lódzkie (slightly smaller numbers and deposits, but a large percentage of the population meeting the criteria).

It is most difficult to find an investor among women living in the Subcarpathia Province.

A smaller average balance is noticeable on the accounts held by women, as well as the number relative to the population being less favourable on accounts belonging to women. The exception here is the Mazovia Province. 
An interesting and promising route for further research in this area are the statistical and indicative analysis of the presented parameters.

\section{References}

1. Dziawgo, L. (2006). Private banking; Bankowość dla zamożnych klientów. Kraków: Oficyna Ekonomiczna Wolters Kluwer.

2. Fatuła, D. (2007). Struktura depozytów i kredytów bankowych gospodarstw domowych w 2006 roku. Finansowe uwarunkowania decyzji ekonomicznych. Kraków: Krakowska Szkoła Wyższa im. Andrzeja Frycza Modrzewskiego.

3. Iwanicz-Drozdowska, M. (2008). Bezpieczeństwo rynku ustug finansowych. Perspektywa Unii Europejskiej. Warszawa: Szkoła Główna Handlowa.

4. Kolasa, A. (2017). Sytuacja finansowa sektora gospodarstw domowych w I kw. 2017 r. Warszawa: Departament Analiz Ekonomicznych NBP.

5. Ludność. Stan i struktura oraz ruch naturalny $w$ przekroju terytorialnym $w 2018$ r. Stan $w$ dniu 31 XII. https://stat.gov.pl/obszary-tematyczne/ludnosc/ludnosc/ludnosc-stan-istruktura-oraz-ruch-naturalny-w-przekroju-terytorialnym-w-2018-r-stan-w-dniu-31xii,6,25.html. 07.07.2020.

6. Smith, W. (1956). Product Differentiation and Marketing Segmentation as Alternative Marketing Strategies. Journal of Marketing.

7. Strzelecka, A. (2010). Zmiany w strukturze nadwyżek finansowych rolników indywidualnych w Polsce lokowanych w bankach w latach 2000-2010. Zeszyty Naukowe Szkoły Głównej Gospodarstwa Wiejskiego w Warszawie. Ekonomika i Organizacja Gospodarki Żywnościowej, $n r$ 82, p. 257.

8. Szulce, H., Walkowiak, K., and Florek, M. (2004). Segmentacja jako podstawa zróżnicowania działań marketingowych. Acta Universitatis Lodziensis. Folia Oeconomica $n r$ 179, cz. 1. Łódź: Wydawnictwo Uniwersytetu Łódzkiego.

9. Walesiak, M. (2013). Segmentacja rynku. Kryteria i metody. In: A. Zeliaś, Przestrzennoczasowe modelowanie i prognozowanie zjawisk gospodarczych (pp. 191-201). Kraków: Wydawnictwo AE.

10. Witkowska-Masłowska, M. (2006). Zyskowność klienta banku komercyjnego - koncepcje i kalkulacje. In: M. Zaleska, J. Węcławski, Bankowość. Lublin: Wydawnictwo Uniwersytetu Marii Curie-Skłodowskiej. 